\title{
Salegentibacter salinarum sp. nov., isolated from a marine solar saltern
}

\author{
Jung-Hoon Yoon, Mi-Hwa Lee, So-Jung Kang and Tae-Kwang Oh \\ Korea Research Institute of Bioscience and Biotechnology (KRIBB), PO Box 115, Yusong, Taejon, \\ Republic of Korea
}

Correspondence

Jung-Hoon Yoon

jhyoon@kribb.re.kr

\begin{abstract}
A bacterial strain, ISL-4 ${ }^{\top}$, comprising Gram-negative, non-motile, rod-shaped cells, was isolated from a marine solar saltern of the Yellow Sea in Korea and was subjected to a polyphasic taxonomic investigation. Phenotypically, the strain resembled members of the genus Salegentibacter. It grew optimally at $\mathrm{pH} 7.0-8.0$ and $30{ }^{\circ} \mathrm{C}$ and in the presence of $8 \%(\mathrm{w} / \mathrm{v})$ $\mathrm{NaCl}$. It contained MK-6 as the predominant menaquinone. The major fatty acids were iso- $\mathrm{C}_{15: 0}$ and anteiso- $\mathrm{C}_{15: 0}$. The DNA G $+\mathrm{C}$ content was $37.9 \mathrm{~mol} \%$. A phylogenetic analysis based on 16S rRNA gene sequences showed that strain ISL $-4^{\top}$ belonged to the genus Salegentibacter, exhibiting sequence similarity values of 95.9-98.6\% with respect to the type strains of recognized Salegentibacter species (with the exception of Salegentibacter catena). Low DNA-DNA relatedness values and differential phenotypic properties, together with its phylogenetic distinctiveness, demonstrated that strain ISL $-4^{\top}$ represents a novel species of the genus Salegentibacter, for which the name Salegentibacter salinarum sp. nov. is proposed. The type strain is ISL-4 $4^{\top}\left(=\right.$ KCTC $12975^{\top}=$ CCUG $\left.54354^{\top}\right)$.
\end{abstract}

The genus Salegentibacter was created by McCammon \& Bowman (2000) from the reclassification of [Flavobacterium] salegens as Salegentibacter salegens. At the time of writing, seven Salegentibacter species have been described, having been isolated from hypersaline lake water, marine water, sediment and invertebrates: S. salegens (McCammon \& Bowman, 2000), Salegentibacter holothuriorum (Nedashkovskaya et al., 2004), Salegentibacter mishustinae (Nedashkovskaya et al., 2005), Salegentibacter flavus (Ivanova et al., 2006), Salegentibacter agarivorans (Nedashkovskaya et al., 2006), Salegentibacter catena (Ying et al., 2007) and Salegentibacter salarius (Yoon et al., 2007). However, it has been noted that $S$. catena should be reclassified to another (or a novel) genus because of its very distinct phylogenetic position (Yoon et al., 2007). In this study, we report on the taxonomic characterization of a Salegentibacter-like bacterial strain, ISL- $4^{\mathrm{T}}$, isolated from a marine solar saltern in Korea.

Strain ISL- ${ }^{\mathrm{T}}$ was isolated by means of the dilution plating technique at $25{ }^{\circ} \mathrm{C}$ on marine agar 2216 (MA; Difco) supplemented with $8 \%(\mathrm{w} / \mathrm{v}) \mathrm{NaCl}$. The type strains of all Salegentibacter species except $S$. catena were used as reference strains for DNA-DNA hybridization. S. holothuriorum LMG $21968^{\mathrm{T}}$ and S. salegens LMG $13193^{\mathrm{T}}$ were obtained from the Laboratorium voor Microbiologie Universiteit Gent (Ghent, Belgium), S. mishustinae KCTC $12263^{\mathrm{T}}$ and S. agarivorans KCTC $12560^{\mathrm{T}}$ were obtained

The GenBank/EMBL/DDBJ accession number for the 16S rRNA gene sequence of strain ISL-4 ${ }^{\top}$ is EF612764. from the Korean Collection for Type Cultures (Taejon, Korea), S. flavus CIP $107843^{\mathrm{T}}$ was obtained from the Collection de l'Institut Pasteur (Paris, France) and $S$. salarius ISL- $6^{\mathrm{T}}$ was maintained in our laboratory (Yoon et al., 2007). The morphological, physiological and biochemical characteristics of strain ISL- ${ }^{\mathrm{T}}$ were investigated using routine cultivation on MA supplemented with $6 \%(\mathrm{w} / \mathrm{v}) \mathrm{NaCl}$ at $30{ }^{\circ} \mathrm{C}$. Cell morphology was examined by using light microscopy (E600; Nikon) and transmission electron microscopy (CM-20; Philips). Flagellation was investigated by using transmission electron microscopy on cells from an exponentially growing culture negatively stained with $1 \%(\mathrm{w} / \mathrm{v})$ phosphotungstic acid; grids were examined after being air-dried. Gliding motility was investigated as described by Bowman (2000). The Gram reaction was determined by using the bioMérieux Gramstain kit according to the manufacturer's instructions. Growth under anaerobic conditions was determined after incubation in a Forma anaerobic chamber on MA supplemented with $6 \%(\mathrm{w} / \mathrm{v}) \mathrm{NaCl}$ and on MA supplemented with $6 \%(\mathrm{w} / \mathrm{v}) \mathrm{NaCl}$ and $0.1 \%(\mathrm{w} / \mathrm{v})$ potassium nitrate, both of which had been prepared under a nitrogen atmosphere. Growth in the absence of $\mathrm{NaCl}$ was investigated using trypticase soy broth prepared according to the formula of the Difco medium except that $\mathrm{NaCl}$ was excluded and $0.45 \%(\mathrm{w} / \mathrm{v}) \mathrm{MgCl}_{2} \cdot 6 \mathrm{H}_{2} \mathrm{O}$ was added. Growth with $\mathrm{NaCl}$ at various concentrations (1-20\%, using $1 \%$ increments) was investigated in marine broth 2216 (MB; Difco) and trypticase soy broth (Difco), both of which were supplemented with $0.45 \%(\mathrm{w} / \mathrm{v}) \mathrm{MgCl}_{2} \cdot 6 \mathrm{H}_{2} \mathrm{O}$. Any requirement for $\mathrm{Mg}^{2+}$ ions was investigated in the 
presence and absence of $\mathrm{MgCl}_{2} \cdot 6 \mathrm{H}_{2} \mathrm{O}(0.45 \%$, w/v) at various $\mathrm{NaCl}$ concentrations $(0-5 \%$, using $1 \%$ increments) by using trypticase soy broth prepared according to the formula of the Difco medium except that $\mathrm{NaCl}$ was excluded. Growth at various temperatures $(4,10,15,20,25$ and 28 and $30-45{ }^{\circ} \mathrm{C}$, using $1{ }^{\circ} \mathrm{C}$ increments) was measured on MA supplemented with $6 \%(\mathrm{w} / \mathrm{v}) \mathrm{NaCl}$. The $\mathrm{pH}$ range for growth was determined in $\mathrm{MB}$ supplemented with $6 \%(\mathrm{w} / \mathrm{v}) \mathrm{NaCl}$ and adjusted to various $\mathrm{pH}$ values ( $\mathrm{pH} 4.5-9.5$, using increments of $0.5 \mathrm{pH}$ units) after autoclaving. Catalase and oxidase activities were determined as described by Cowan \& Steel (1965). DNase activity was investigated by using DNase test agar with methyl green (Difco) and $8 \%(\mathrm{w} / \mathrm{v}) \mathrm{NaCl}$. Hydrolysis of casein, starch, Tweens 20,40,60 and 80, hypoxanthine, tyrosine and xanthine was tested on MA supplemented with $6 \%(\mathrm{w} / \mathrm{v}) \mathrm{NaCl}$ by using the substrate concentrations described by Cowan \& Steel (1965). Hydrolysis of aesculin, gelatin and urea and reduction of nitrate were investigated as described previously (Lanyi, 1987) but with the modification that artificial seawater supplemented with $6 \%(\mathrm{w} / \mathrm{v}) \mathrm{NaCl}$ was used for the preparation of media. The artificial seawater contained the following $\left(\mathrm{l}^{-1}\right.$ distilled water): $23.6 \mathrm{~g} \mathrm{NaCl}, 0.64 \mathrm{~g} \mathrm{KCl}, 4.53 \mathrm{~g} \mathrm{MgCl}_{2} \cdot 6 \mathrm{H}_{2} \mathrm{O}$, $5.94 \mathrm{~g} \mathrm{MgSO}_{4} \cdot 7 \mathrm{H}_{2} \mathrm{O}$ and $1.3 \mathrm{~g} \mathrm{CaCl}_{2} \cdot 2 \mathrm{H}_{2} \mathrm{O}$ (Bruns et al., 2001). $\mathrm{H}_{2} \mathrm{~S}$ production was tested as described previously (Bruns et al., 2001). The presence of flexirubin-type pigments was investigated as described by Reichenbach (1992). Susceptibility to antibiotics was investigated on MA plates supplemented with $6 \%(\mathrm{w} / \mathrm{v}) \mathrm{NaCl}$ by using antibiotic discs with the following concentrations: polymyxin B, $100 \mathrm{IU}$; streptomycin, $50 \mu \mathrm{g}$; penicillin G, $20 \mathrm{IU}$; chloramphenicol, $100 \mu \mathrm{g}$; ampicillin, $10 \mu \mathrm{g}$; cephalothin, $30 \mu \mathrm{g}$; gentamicin, $30 \mu \mathrm{g}$; novobiocin, $5 \mu \mathrm{g}$; tetracycline, $30 \mu \mathrm{g}$; kanamycin, $30 \mu \mathrm{g}$; lincomycin, $15 \mu \mathrm{g}$; oleandomycin, $15 \mu \mathrm{g}$; neomycin, $30 \mu \mathrm{g}$; and carbenicillin, $100 \mu \mathrm{g}$. Acid production from carbohydrates was tested as described by Leifson (1963), using supplementation with $7 \%(\mathrm{w} / \mathrm{v}) \mathrm{NaCl}$. The utilization of various substrates for growth was determined as described by Yurkov et al. (1994), using supplementation with $6.5 \%(\mathrm{w} / \mathrm{v}) \mathrm{NaCl}$. Enzyme activities were determined by using the API ZYM system (bioMérieux).

Cell biomass for DNA extraction and for isoprenoid quinone analysis was obtained from a culture grown at $30{ }^{\circ} \mathrm{C}$ in $\mathrm{MB}$ supplemented with $6 \%(\mathrm{w} / \mathrm{v}) \mathrm{NaCl}$. Chromosomal DNA was isolated and purified according to the method described by Yoon et al. (1996), with the modification that RNase $\mathrm{T} 1$ was used in combination with RNase A to minimize contamination by RNA. The $16 \mathrm{~S}$ rRNA gene was amplified with a PCR using two universal primers, as described previously (Yoon et al., 1998). Sequencing of the amplified 16S rRNA gene and phylogenetic analysis were performed as described by Yoon et al. (2003). Isoprenoid quinones were analysed as described by Komagata \& Suzuki (1987), using reversed-phase HPLC. For cellular fatty acid analysis, cell mass of strain ISL- $4^{\mathrm{T}}$ was harvested after cultivation for 7 days at $30{ }^{\circ} \mathrm{C}$ on MA supplemented with $6 \%(\mathrm{w} / \mathrm{v}) \mathrm{NaCl}$. The fatty acids were extracted and the fatty acid methyl esters prepared according to the standard protocol of the MIDI/Hewlett Packard Microbial Identification System (Sasser, 1990). The DNA G $+\mathrm{C}$ content was determined by using the method of Tamaoka \& Komagata (1984), with the modification that DNA was hydrolysed using nuclease P1 (Sigma) and the resultant nucleotides were analysed by reversed-phase HPLC. DNA-DNA hybridization was performed fluorometrically with the method of Ezaki et al. (1989), using photobiotin-labelled DNA probes and microdilution wells. Hybridization was performed with five replications for each sample. The highest and lowest values obtained for each sample were excluded and the means of the remaining three values were quoted as DNA-DNA relatedness values.

Morphological, cultural, physiological and biochemical characteristics of strain ISL- $4^{\mathrm{T}}$ are given in the species description and in Table 1. The almost-complete $16 \mathrm{~S}$ rRNA gene sequence of strain ISL- ${ }^{\mathrm{T}}$ comprised $1485 \mathrm{nt}$, representing approximately $96 \%$ of the Escherichia coli 16S rRNA gene sequence. In the neighbour-joining phylogenetic tree constructed on the basis of 16S rRNA gene sequences, strain ISL- ${ }^{\mathrm{T}}$ fell within the cluster comprising all Salegentibacter species except S. catena (Fig. 1). The overall topology of the trees generated with the maximum-likelihood and maximum-parsimony algorithms was similar. Strain ISL- $4^{\mathrm{T}}$ exhibited $16 \mathrm{~S}$ rRNA gene sequence similarity values of 98.6, 98.6, 98.2, 97.8, 97.5, 95.9 and $93.0 \%$ with respect to the type strains of $S$. agarivorans, S. salegens, S. mishustinae, S. salarius, $S$. holothuriorum, S. flavus and S. catena, respectively. The sequence similarity values with respect to other species used in the phylogenetic analysis were below $93.2 \%$. The predominant isoprenoid quinone detected in strain ISL- $4^{\mathrm{T}}$ was MK-6, at a peak area ratio of approximately $92 \%$. The fatty acid profile of strain ISL $-4^{\mathrm{T}}$ was composed of the following (each constituting $>0.5 \%$ of total fatty acids): branched fatty acids iso- $\mathrm{C}_{15: 0}(15.9 \%)$, anteiso- $\mathrm{C}_{15: 0}$ $(12.6 \%)$, iso- $\mathrm{C}_{16: 0}(5.7 \%)$, iso- $\mathrm{C}_{15: 1}(5.4 \%)$, iso- $\mathrm{C}_{16: 1}$ $(3.1 \%)$, anteiso- $\mathrm{C}_{17: 1} \omega 9 c(3.5 \%)$, iso- $\mathrm{C}_{17: 1} \omega 9 c(2.8 \%)$, iso- $\mathrm{C}_{14: 0}(1.3 \%)$ and anteiso- $\mathrm{C}_{15: 1}(0.8 \%)$; hydroxy fatty acids iso- $\mathrm{C}_{17: 0} 3-\mathrm{OH}(7.7 \%), \mathrm{C}_{17: 0} 2-\mathrm{OH}(6.5 \%)$, iso$\mathrm{C}_{16: 0} 3-\mathrm{OH}(6.2 \%), \mathrm{C}_{15: 0} 2-\mathrm{OH}(2.4 \%)$, iso- $\mathrm{C}_{15: 0} 3-\mathrm{OH}$ $(2.0 \%)$ and $\mathrm{C}_{16: 0} 3-\mathrm{OH}(0.6 \%)$; summed feature 3 $\left(\mathrm{C}_{16: 1} \omega 7 c\right.$ and/or iso- $\left.\mathrm{C}_{15: 0} 2-\mathrm{OH}, 7.8 \%\right)$; straight-chain fatty acids $\mathrm{C}_{15: 0}(6.5 \%)$ and $\mathrm{C}_{16: 0}(0.7 \%)$; unsaturated fatty acids $\mathrm{C}_{17: 1} \omega 6 c(3.1 \%), \mathrm{C}_{15: 1} \omega 6 c \quad(2.7 \%)$ and $\mathrm{C}_{18: 1} \omega 5 c(0.7 \%)$; and an unknown fatty acid with an equivalent chain length of $16.582(0.8 \%)$. This fatty acid profile was similar to those of Salegentibacter species, although there were slight differences in the proportions of some fatty acids. These differences might result partly from different cultivation conditions and extraction procedures (Ivanova et al., 2006; Nedashkovskaya et al., 2004, 2005, 2006; Yoon et al., 2007). The DNA G + C content of strain 
Table 1. Differential phenotypic characteristics of strain ISL-4 ${ }^{\top}$ and Salegentibacter type strains

Strains: 1, ISL- $4^{\mathrm{T}}$ (this study); 2, S. salegens ACAM $48^{\mathrm{T}}$ (Dobson et al., 1993; Nedashkovskaya et al., 2004, 2005, 2006); 3, S. holothuriorum KMM $3524^{\mathrm{T}}$ (Nedashkovskaya et al., 2004, 2006); 4, S. mishustinae KMM $6049^{\mathrm{T}}$ (Nedashkovskaya et al., 2005); 5, S. flavus KMM $6000^{\mathrm{T}}$ (Ivanova et al., 2006); 6, S. agarivorans KMM $7019^{\mathrm{T}}$ (Nedashkovskaya et al., 2006); 7, S. salarius ISL-6 ${ }^{\mathrm{T}}$ (Yoon et al., 2007). S. catena was not included because of its very distinct phylogenetic position. All of the strains were positive for catalase and oxidase activities, hydrolysis of Tween 20, Tween 40 (not determined for S. flavus) and starch and for growth at $34{ }^{\circ} \mathrm{C}$ and in the presence of $8 \% \mathrm{NaCl}$. All of the strains were negative for the production of flexirubin-type pigments and for the production of acid from sorbitol, inositol and mannitol. +, Positive; -, negative; w, weakly positive; ND, no data available.

\begin{tabular}{|c|c|c|c|c|c|c|c|}
\hline Characteristic & 1 & 2 & 3 & 4 & 5 & 6 & 7 \\
\hline Gliding motility & - & - & - & - & - & + & - \\
\hline $\begin{array}{l}\mathrm{NaCl} \text { requirement for } \\
\text { growth }\end{array}$ & + & $-*$ & $+\dagger$ & + & + & + & + \\
\hline Nitrate reduction & - & + & - & - & - & + & - \\
\hline Production of $\mathrm{H}_{2} \mathrm{~S}$ & - & $-\ddagger$ & + & + & - & + & - \\
\hline \multicolumn{8}{|l|}{ Growth at/with: } \\
\hline $37^{\circ} \mathrm{C}$ & + & - & + & - & - & + & + \\
\hline $41{ }^{\circ} \mathrm{C}$ & + & - & - & - & - & + & + \\
\hline $12 \%(\mathrm{w} / \mathrm{v}) \mathrm{NaCl}$ & + & + & - & + & - & + & + \\
\hline $18 \%(\mathrm{w} / \mathrm{v}) \mathrm{NaCl}$ & - & + & - & + & - & + & - \\
\hline \multicolumn{8}{|l|}{ Hydrolysis of: } \\
\hline Agar & - & - & - & - & - & + & - \\
\hline Casein & + & - & - & + & - & - & + \\
\hline DNA & + & + & + & - & $\mathrm{ND}$ & + & + \\
\hline Gelatin & - & + & + & + & $\mathrm{W}$ & + & - \\
\hline Urea & - & - & - & - & + & - & - \\
\hline \multicolumn{8}{|l|}{ Acid production from: } \\
\hline $\begin{array}{l}\text { L-Arabinose, D-xylose, } \\
\text { cellobiose }\end{array}$ & + & $-\S$ & - & - & -11 & + & - \\
\hline Sucrose, raffinose & + & - & - & + & ND & + & + \\
\hline D-Galactose, D-glucose & + & + & + & - & ND & + & - \\
\hline Lactose & + & - & + & - & ND & + & - \\
\hline Maltose & + & + & + & + & ND & + & - \\
\hline L-Rhamnose & + & - & - & - & - & - & - \\
\hline \multicolumn{8}{|l|}{ Utilization of: } \\
\hline L-Arabinose & + & - & - & - & - & + & - \\
\hline D-Glucose & + & + & + & + & - & + & - \\
\hline Sucrose & + & + & - & + & - & + & - \\
\hline \multicolumn{8}{|l|}{ Susceptibility to: } \\
\hline Ampicillin & - & + & + & + & ND & - & + \\
\hline $\begin{array}{l}\text { Benzylpenicillin, } \\
\text { lincomycin }\end{array}$ & + & + & + & + & ND & - & + \\
\hline Carbenicillin & + & + & + & - & ND & - & + \\
\hline Kanamycin, neomycin & - & - & - & - & ND & + & - \\
\hline Streptomycin & - & + & - & - & $\mathrm{ND}$ & + & - \\
\hline Tetracycline & - & + & + & + & ND & - & - \\
\hline $\begin{array}{l}\text { DNA G }+ \text { C content } \\
(\mathrm{mol} \%)\end{array}$ & 37.9 & 419 & 36.8 & 37.5 & $40-41$ & 39.23 & 37.5 \\
\hline
\end{tabular}

${ }^{\star}$ Reported as negative by McCammon \& Bowman (2000) and Nedashkovskaya et al. $(2005,2006)$, but positive by Nedashkovskaya et al. (2004) and Ivanova et al. (2006). $\dagger$ Reported as positive by Nedashkovskaya et al. (2004, 2005, 2006), but negative by Ivanova et al. (2006).

$\ddagger$ Reported as negative by Dobson et al. (1993), but positive by Nedashkovskaya et al. $(2004,2005,2006)$ and Ivanova et al. (2006). §Reported as positive for L-arabinose by Dobson et al. (1993), but negative by Nedashkovskaya et al. $(2004,2005,2006)$ and Ivanova et al. (2006).

IINo data available for cellobiose.

SData from Dobson et al. (1993); reported as $37-38 \mathrm{~mol} \%$ by McCammon \& Bowman (2000), 36.7 mol\% by Nedashkovskaya et al. (2004) and Ivanova et al. (2006) and $37.8 \mathrm{~mol} \%$ by Nedashkovskaya et al. $(2005,2006)$.

ISL- $4^{\mathrm{T}}$ was $37.9 \mathrm{~mol} \%$. The results of chemotaxonomic analyses were consistent with the phylogenetic data. Accordingly, strain ISL $-4^{\mathrm{T}}$ should be considered as a member of the genus Salegentibacter (Ivanova et al., 2006; Nedashkovskaya et al., 2004, 2005, 2006; Yoon et al., 2007).

Strain ISL- $4^{\mathrm{T}}$ exhibited DNA-DNA relatedness values of $11-24 \%$ with respect to the type strains of the six more closely related Salegentibacter species, indicating that it represents a separate genomic species (Wayne et al., 1987). Moreover, strain ISL $-4^{\mathrm{T}}$ was distinguishable from these six Salegentibacter species on the basis of several phenotypic differences (Table 1). Hence, the phylogenetic and genetic distinctiveness and differential phenotypic properties of strain ISL $-4^{\mathrm{T}}$ support its description as a representative of a novel species within the genus Salegentibacter, for which the name Salegentibacter salinarum sp. nov. is proposed.

\section{Description of Salegentibacter salinarum sp. nov.}

Salegentibacter salinarum (sa.li.na'rum. L. pl. gen. n. salinarum of salterns).

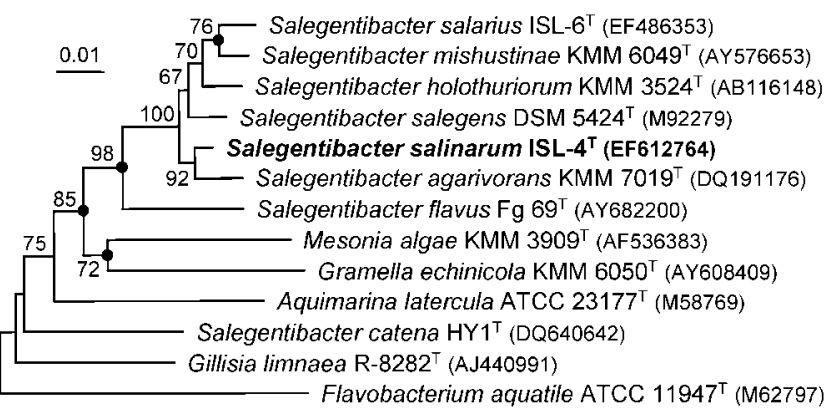

Fig. 1. Neighbour-joining phylogenetic tree, based on 16S rRNA gene sequences, showing the positions of strain ISL- $4^{\top}$, Salegentibacter species and some other related taxa. Bootstrap values (expressed as percentages of 1000 replications) $>50 \%$ are shown at branching points. Filled circles indicate that the corresponding nodes were also recovered in trees generated with the maximum-likelihood and maximum-parsimony algorithms. Flavobacterium aquatile ATCC $11947^{\top}$ was used as an outgroup. Bar, 0.01 substitutions per nucleotide position. 
Cells are Gram-negative, non-motile rods, $0.5-0.8 \mu \mathrm{m}$ in diameter and $1.0-5.5 \mu \mathrm{m}$ in length. Colonies on MA supplemented with $6 \%(\mathrm{w} / \mathrm{v}) \mathrm{NaCl}$ are circular, convex, smooth, glistening, yellow-coloured and $1.0-1.5 \mathrm{~mm}$ in diameter after 7 days incubation at $30{ }^{\circ} \mathrm{C}$. Growth occurs at $4-41{ }^{\circ} \mathrm{C}$ and $\mathrm{pH} 5.5$ and in the presence of $2-17 \%(\mathrm{w} / \mathrm{v})$ $\mathrm{NaCl}$. Optimal growth is observed at $30{ }^{\circ} \mathrm{C}$ and $\mathrm{pH} 7.0-8.0$ and with $8 \%(\mathrm{w} / \mathrm{v}) \mathrm{NaCl}$. The $\mathrm{Mg}^{2+}$ ion is required for growth. Growth does not occur under anaerobic conditions. Flexirubin-type pigments are not produced. Aesculin, L-tyrosine, Tween 60 and Tween 80 are hydrolysed, but hypoxanthine and xanthine are not. Maltose, Dmannose, trehalose, pyruvate and salicin are utilized, but cellobiose, D-fructose, D-galactose, D-xylose, acetate, citrate, succinate, benzoate, L-malate, formate and L-glutamate are not. Acid is produced from D-fructose, D-mannose, melezitose and trehalose, but not from melibiose or Dribose. Susceptible to cephalothin, chloramphenicol, novobiocin and oleandomycin, but not to gentamicin or polymyxin B. In the API ZYM system, alkaline phosphatase, esterase (C4), esterase lipase (C8), leucine arylamidase, valine arylamidase, acid phosphatase, naphthol-AS-BI phosphohydrolase, $\alpha$-glucosidase and $N$-acetyl- $\beta$-glucosaminidase activities are present, but lipase (C14), cystine arylamidase, trypsin, $\alpha$-chymotrypsin, $\alpha$-galactosidase, $\beta$ galactosidase, $\beta$-glucuronidase, $\beta$-glucosidase, $\alpha$-mannosidase and $\alpha$-fucosidase activities are absent. The predominant menaquinone is MK-6. The major fatty acids $(>10 \%$ of total fatty acids) are iso- $\mathrm{C}_{15: 0}$ and anteiso- $\mathrm{C}_{15: 0}$. The DNA G + C content of the type strain is $37.9 \mathrm{~mol} \%$ (determined by HPLC). Other phenotypic characteristics are given in Table 1.

The type strain, ISL- $4^{\mathrm{T}}\left(=\right.$ KCTC $12975^{\mathrm{T}}=$ CCUG $\left.54354^{\mathrm{T}}\right)$, was isolated from a marine solar saltern of the Yellow Sea, Korea.

\section{Acknowledgements}

This work was supported by the 21C Frontier Program of Microbial Genomics and Applications (grant MG05-0401-2-0) and the Support and Application Project of Biological Resources (grant M10508050004-06N0805-00410) from the Ministry of Science and Technology (MOST) of the Republic of Korea.

\section{References}

Bowman, J. P. (2000). Description of Cellulophaga algicola sp. nov., isolated from the surfaces of Antarctic algae, and reclassification of Cytophaga uliginosa (ZoBell and Upham 1944) Reichenbach 1989 as Cellulophaga uliginosa comb. nov. Int J Syst Evol Microbiol 50, 1861-1868.

Bruns, A., Rohde, M. \& Berthe-Corti, L. (2001). Muricauda ruestringensis gen. nov., sp. nov., a facultatively anaerobic, appendaged bacterium from German North Sea intertidal sediment. Int $J$ Syst Evol Microbiol 51, 1997-2006.

Cowan, S. T. \& Steel, K. J. (1965). Manual for the Identification of Medical Bacteria. London: Cambridge University Press.

Dobson, S. J., Colwell, R. R., McMeekin, T. A. \& Franzmann, P. D. (1993). Direct sequencing of the polymerase chain reaction-amplified
$16 \mathrm{~S}$ rRNA gene of Flavobacterium gondwanense sp. nov. and Flavobacterium salegens sp. nov., two new species from a hypersaline Antarctic lake. Int J Syst Bacteriol 43, 77-83.

Ezaki, T., Hashimoto, Y. \& Yabuuchi, E. (1989). Fluorometric deoxyribonucleic acid-deoxyribonucleic acid hybridization in microdilution wells as an alternative to membrane filter hybridization in which radioisotopes are used to determine genetic relatedness among bacterial strains. Int J Syst Bacteriol 39, 224-229.

Ivanova, E. P., Bowman, J. P., Christen, R., Zhukova, N. V., Lysenko, A. M., Gorshkova, N. M., Mitik-Dineva, N., Sergeev, A. F. \& Mikhailov, V. V. (2006). Salegentibacter flavus sp. nov. Int J Syst Evol Microbiol 56, 583-586.

Komagata, K. \& Suzuki, K. (1987). Lipid and cell-wall analysis in bacterial systematics. Methods Microbiol 19, 161-207.

Lanyi, B. (1987). Classical and rapid identification methods for medically important bacteria. Methods Microbiol 19, 1-67.

Leifson, E. (1963). Determination of carbohydrate metabolism of marine bacteria. J Bacteriol 85, 1183-1184.

McCammon, S. A. \& Bowman, J. P. (2000). Taxonomy of Antarctic Flavobacterium species: description of Flavobacterium gillisiae sp. nov., Flavobacterium tegetincola sp. nov. and Flavobacterium xanthum sp. nov., nom. rev. and reclassification of [Flavobacterium] salegens as Salegentibacter salegens gen. nov., comb. nov. Int J Syst Evol Microbiol 50, 1055-1063.

Nedashkovskaya, O. I., Suzuki, M., Vancanneyt, M., Cleenwerck, I., Zhukova, N. V., Vysotskii, M. V., Mikhailov, V. V. \& Swings, J. (2004). Salegentibacter holothuriorum sp. nov., isolated from the edible holothurian Apostichopus japonicus. Int J Syst Evol Microbiol 54, 1107-1110.

Nedashkovskaya, O. I., Kim, S. B., Lysenko, A. M., Mikhailov, V. V., Bae, K. S. \& Kim, I. S. (2005). Salegentibacter mishustinae sp. nov., isolated from the sea urchin Strongylocentrotus intermedius. Int J Syst Evol Microbiol 55, 235-238.

Nedashkovskaya, O. I., Kim, S. B., Vancanneyt, M., Shin, D. S., Lysenko, A. M., Shevchenko, L. S., Krasokhin, V. B., Mikhailov, V. V., Swings, J. \& Bae, K. S. (2006). Salegentibacter agarivorans sp. nov., a novel marine bacterium of the family Flavobacteriaceae isolated from the sponge Artemisina sp. Int J Syst Evol Microbiol 56, 883-887.

Reichenbach, H. (1992). The order Cytophagales. In The Prokaryotes. A Handbook on the Biology of Bacteria: Ecophysiology, Isolation, Identification, Applications, 2nd edn, pp. 3631-3675. Edited by A. Balows, H. G. Trüper, M. Dworkin, W. Harder \& K. H. Schleifer. New York: Springer.

Sasser, M. (1990). Identification of bacteria by gas chromatography of cellular fatty acids, MIDI Technical Note 101. Newark, DE: MIDI Inc.

Tamaoka, J. \& Komagata, K. (1984). Determination of DNA base composition by reversed-phase high-performance liquid chromatography. FEMS Microbiol Lett 25, 125-128.

Wayne, L. G., Brenner, D. J., Colwell, R. R., Grimont, P. A. D., Kandler, O., Krichevsky, M. I., Moore, L. H., Moore, W. E. C., Murray, R. G. E. \& other authors (1987). International Committee on Systematic Bacteriology. Report of the ad hoc committee on reconciliation of approaches to bacterial systematics. Int J Syst Bacteriol 37, 463-464.

Ying, J.-Y., Liu, Z.-P., Wang, B.-J., Dai, X., Yang, S.-S. \& Liu, S.-J. (2007). Salegentibacter catena sp. nov., isolated from sediment of the South China Sea, and emended description of the genus Salegentibacter. Int J Syst Evol Microbiol 57, 219-222.

Yoon, J.-H., Kim, H., Kim, S.-B., Kim, H.-J., Kim, W. Y., Lee, S. T., Goodfellow, M. \& Park, Y.-H. (1996). Identification of 
Saccharomonospora strains by the use of genomic DNA fragments and rRNA gene probes. Int J Syst Bacteriol 46, 502-505.

Yoon, J.-H., Lee, S. T. \& Park, Y.-H. (1998). Inter- and intraspecific phylogenetic analysis of the genus Nocardioides and related taxa based on 16S rDNA sequences. Int J Syst Bacteriol 48, 187-194.

Yoon, J.-H., Kim, I.-G., Shin, D.-Y., Kang, K. H. \& Park, Y.-H. (2003). Microbulbifer salipaludis sp. nov., a moderate halophile isolated from a Korean salt marsh. Int J Syst Evol Microbiol 53, 53-57.
Yoon, J.-H., Jung, S.-Y., Kang, S.-J., Jung, Y.-T. \& Oh, T.-K. (2007). Salegentibacter salarius sp. nov., isolated from a marine solar saltern. Int J Syst Evol Microbiol 57, 2738-2742.

Yurkov, V., Stackebrandt, E., Holmes, A., Fuerst, J. A., Hugenholtz, P., Golecki, J., Gad'on, N., Gorlenko, V. M., Kompantseva, E. I. \& Drews, G. (1994). Phylogenetic positions of novel aerobic, bacteriochlorophyll acontaining bacteria and description of Roseococcus thiosulfatophilus gen. nov., sp. nov., Erythromicrobium ramosum gen. nov., sp. nov., and Erythrobacter litoralis sp. nov. Int J Syst Bacteriol 44, 427-434. 